\title{
Stres Yönetimi Eğitiminin Bakım Personeli Tarafından Algılanan Stres Düzeyine Etkisi
}

Effect of Stress Management Training on Level of Perceived Stress by Care Staff

\author{
Esin CERIT 1 \\ ${ }^{1}$ Dr. Öğr. Üyesi, Yozgat Bozok Üniversitesi Sağlık Bilimleri Fakültesi, Yozgat, Türkiye
}

\section{öz}

\begin{abstract}
Amaç: Bu çalışma, bakım ve rehabilitasyon merkezinde çalışan bakım personeline verilen stres yönetimi eğitiminin, bakım personellerinin algıladıkları stres düzeyine etkisini değerlendirmek amacıyla yapıldı. Gereç ve Yöntem: Çalışma, ön-test son-test kontrol grupsuz desende planlandı. Bu çalışmada, Yozgat'ta 26'sı kadın, 23'ü erkek ve yaş ortalaması 41,6 6 ,5 yıl olan 49 bakım personeline iki gün süren 45 'er dakikalık iki oturumdan oluşan stres yönetimi eğitimi verildi. Veriler, personelin tanıtıcı özelliklerini içeren sekiz sorudan oluşan tanımlayıcı bilgi formu ve Algılanan Stres Ölçeği aracııığıyla toplandı. Bakım personelinin tanımlayıcı özellikleri sayı, yüzde ve ortalama şeklinde belirtildi. Eğitim öncesi ve eğitim sonrası ölçekten alınan puan ortalamalarının karşılaşıtııımasında Bağımlı iki örneklem t testi, Bağımsız iki örneklem t testi ve Tek yönlü varyans analizi kullanıldı. Sonuçlar: Bakım personelinin eğitim öncesi

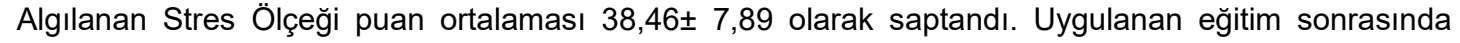
personelin algıladığı stres düzeyinde anlamlı bir farklıık olmamakla $(p>0.05)$ birlikte azalma olduğu belirlendi. Tartışma: Çalışmanın sonucunda, uygulanan stres yönetimi eğitiminin bakım personelinin stresini azaltmada etkili olduğunu söyleyememekteyiz fakat eğitim sonrası algıladıkları stres düzeyinde azalma olması olumlu bir gelişmedir. Araştırmadan elde edilen sonuçlara göre yeni yapılacak çalışmalarda, pekiştirici nitelikte daha fazla oturumdan oluşan eğitimler uygulanıp uygulanan eğitimin uzun dönemdeki etkisinin araştııııması önerilebilir.
\end{abstract}

Anahtar Kelimeler: Stres yönetimi; Bakım; Rehabilitasyon; Bakım personeli; Eğitim

ABSTRACT

Purpose: The aim of this study is to evaluate the effect of stress management training on the perceived stress level of care staff working in the care and rehabilitation center. Methods: This study is a pre-test and post-test training research. In this study, stress management training consisting of two 45-minute sessions lasting two days was delivered to 49 caregivers, 26 women, 23 men and the mean age of $41.6 \pm 6.5$ years in Yozgat. Data were collected by means of a descriptive information form and Perceived Stress Scale-14. Identifying characteristics of care staff are indicated in number, percentage and average. Paired Sample t test, Independent sample t test and One Way ANOVA for comparing the mean scores of independent variables the mean scores of Perceived Stress Scale. Results: The care staff's Perceived Stress Scale mean score is $38.46 \pm 7.89$ before training program. It was found that the level of stress perceived by the care staff decreased, although not significant $(p>0.05)$. Discussion: We cannot say that the stress management training applied in the study is effective in reducing the stress of the care staff, but the decrease in the level of stress perceived after the training is a positive improvement. According to the results obtained from the research, applying trainings consisting of more sessions and investigating the long-term effect of the applied training can be recommended for new studies.

Keywords: Stress management; Care; Rehabilitation; Care staff; Training

Sorumlu Yazar (Corresponding Author): Esin CERiT E-mail: esin.cerit@yobu.edu.tr ORCID ID: 0000-0002-0830-1233

Geliş Tarihi (Received): 30.10.2020; Kabul Tarihi (Accepted): 06.12.2021

Bu çalışma, 29 Kasım - 1 Aralık 2018 tarihinde Ankara'da düzenlenen 3. Uluslararası Sağık Bilimleri Kongresi'nde sözel bildiri olarak sunulmuştur. 
Bakım verme; beslenme, giyim, boşaltım gibi temel gereksinimler konusunda yardıma muhtaç olan bireylerin bu gereksinimlerini onların yerine üstlenmedir (TDK, 2019). Bakım verme, bakım veren bireyler için tek bir yardım türü ile sınırlı olmayıp, duygusal, fiziksel, ekonomik açıdan destek vermeyi kapsayan çok boyutlu bir süreçtir (Gel ve Keskin, 2017).

Geçtiğimiz 40-50 yıl içerisinde bilim ve teknoloji alanında yaşanan gelişmeler, insan ömrünün uzamasını sağlamış ve toplumlar yaşlanmaya başlamıştır. Bu gelişme kronik hastalıkları ve engeli olan bireylerin sayısının artmasına bunun sonucunda bakım almaya muhtaç bireylerin sayısında ciddi bir artışa neden olmuştur (Bilir, 2004). Türkiye, 2015 yılı itibariyle $\% 8,2$ 'lik yaşlılık oranıyla genç nüfusa sahip bir ülke gibi görünse de 2023 yılında \%10,2'lik bir oranla çok yaşlı nüfuslu ülkeler arasına gireceği tahmin edilmektedir (TÜIK, 2015). Birleşmiş Milletler günümüzde yaklaşık 20 milyon olan 80 yaş üstü birey sayısının 2050'de (2016) 434 milyona çıkacağını, bu durumda bakım gereksinimi olan birey sayısının her gelecek yıl artacağını vurgulamaktadır (Kusmaul, 2017).

Günümüzde ortalama ömrün uzaması, geleneksel aile yapısından çekirdek aileye geçiş, endüstrileşmenin etkisiyle kadınların iş yaşamına daha fazla dahil olması ve uzayan ömürle birlikte sağlık sorunlarının çoğalması bakıma gereksinim duyan birey sayısının artmasına yol açmaktadır (Folkman, Lazarus, Pimpley ve Novacek, 1987; Zarit, 2004; Danış ve Genç, 2011; Atagün ve ark, 2011). Bu sorunun çözümü için aile bireylerinin desteği yetersiz kalmaktadır. Sosyal devlet anlayışı ve bakım sigortası uygulamaları doğrultusunda ailenin geleneksel bakım rolü giderek kurumsal bakım hizmetiyle yer değiştirmeye başlamıştır (Danış ve Genç, 2011; Atagün ve ark, 2011). Bakım gereksinimi olan bireylere hizmet sunan kurumlar içerisinde bakım ve rehabilitasyon merkezleri önemli bir yere sahiptir. Bakım ve rehabilitasyon merkezleri, bedensel, zihinsel ve ruhsal engelleri nedeniyle günlük yaşamın gereklerine uyma konusunda güçlük yaşayan bireylerin, fonksiyon kayıplarını gidermek, kendi kendilerine yeterli olmalarını sağlayan beceriler kazandırmak ve bu becerileri kazanamayanlara da sürekli bakım vermek üzere kurulan yatılı sosyal hizmet kuruluşlarıdır. Bu kuruluşlarda idari sorumlu, hemşire, psikolog, sosyal hizmet uzmanı, fizyoterapist, diyetisyen, bakım personeli ve teknik işlerden sorumlu multidisipliner bir ekip görev yapmaktadır (Engelli Bireylere Yönelik Özel Bakım Merkezleri Yönetmeliği, 2016). Ekipte görev alan bakım personeli, kurumda kalan bireylerle en yoğun ilişki içerisinde olan ve bakım alan bireyler tarafından en çok ilgi beklenen gruptur. Bakım personeli, ağır çalışma koşullarının olması ve özel gereksinimleri olan bireye bakım verme konusunda yeterli bilgi ve beceriye sahip olmamaları nedeniyle ciddi sorunlar yaşamaktadırlar (Dölek, 2012).

Bakım sağlamada önemli bir rol üstlenen bakım personeli, özel gereksinimleri olan bireylerle sürekli yoğun bir iletişim içerisindeler (Danış ve Genç, 2011). $\mathrm{Bu}$ süreç özel gereksinimleri olan bireylere bakım verme konusunda yeterli bilgi ve beceriye sahip olmayan bakım personelinin stres, yorgunluk, anksiyete, tükenmişlik, uyku problemleri, başta bel ağrıları olmak üzere fiziksel sağlık sorunları, kendine zaman ayıramama gibi pek çok fiziksel, ruhsal, sosyal ve ekonomik sorunlar yaşamasına neden olmaktadır. Bakım personelinin sorunlarını belirlemeye yönelik yapılan çalışma sayısı az olmakla birlikte, çalışmalarda (Hendekçi ve Uğur, 2020; Başol, Sağlam ve Çakır, 2018; Danış ve ark., 2011; Işıkhan, 2018; Brigstocke, Donaldson ve Lalit, 2005) bakım personellerinin yaşadığı sorunların başında stresin geldiği vurgulanmaktadır.

$\mathrm{Bu}$ çalışmada amaç, uygulanan bilgilendirme eğitiminin bakım personelinin algıladığı stres düzeyine olan etkisini değerlendirmektir.

HO: Stres yönetimi eğitiminin bakım personelinin algıladığı stres seviyesinde etkisi yoktur.

\section{GEREÇ VE YÖNTEM}

\section{Araştırma Tipi}

Araştırma, tek gruplu ön test - son test kontrol grupsuz desende bir eğitim değerlendirilmesi çalışmasıdır.

\section{Araştırma Grubu}

Araştırma, Yozgat il merkezinde bulunan bakım ve rehabilitasyon merkezinde gerçekleştirilmiştir. Kurumda 140 bakım personeli görev yapmaktadır. Bakım personelleri günde sekiz saatlik periyotlardan oluşan üç vardiya şeklinde çalışmaktadır. Eğitim, gündüz vardiyasında (gündüz vardiyası 08:00-16:00 saatlerini kapsamaktadır) çalışmakta olan bakım personeline verildi. Araştırmanın örnekleminin belirlenmesinde ek bir yönteme gidilmeyip eğitim almak için gönüllü olan personelin (n:49) tamamına eğitim verildi. Örneklem büyüklüğünün gücü, $\mathrm{G}$ power istatistik programında 0,05 anlamlılık, orta düzeyde $(0,50) \% 96$ olarak belirlenmiştir.

Araştırmaya katılmaya katılmayı kabul eden, kurumda çalışan bakım personelinin (Bakım personeli: 
sağlık meslek liselerinin anestezi teknisyenliği, tıbbi görüntüleme teknisyenliği, tıbbi laboratuvar teknisyenliği, tıbbi sekreterlik, acil tıp teknisyenliği, ortopedik protez ve ortez teknisyenliği, çevre sağlığı teknisyenliği, diş protez teknisyenliği ve benzeri bölümleri hariç diğer bölümlerden mezun olan, liselerin çocuk gelişimi ve eğitimi, engelli veya yaşlı bakımı bölümü ile bu bölümlerin ön lisans programları mezunu olan ya da Milli Eğitim Bakanlığı onaylı asgari 400 saatlik engelli bakım, yaşlı bakım, yaşlı ve hasta refakatçisi modüler programı veya yükseköğretim kurumlarının aynı amaçlı, eşdeğer eğitim programlarından sertifika alan kişiyi ifade etmektedir) (Resmi gazete; Engelli Bireylere Yönelik Özel Bakım Merkezleri Yönetmeliği, 2016) tamamı araştırmaya dahil edildi. Bakım personelinin çalışmanın tamamına katılmaması durumunda çalışmadan çıkarıldı.

\section{Veri Toplama Araçları}

Tanımlayıcı Bilgi Formu: Tanımlayıcı bilgi formu, bakım ve rehabilitasyon merkezinde çalışan bireylere yönelik yapılan çalışmalar (Danış ve ark., 2011; Eskin, Harlak, Demirkıran ve ark., 2013) taranarak oluşturulmuştur. Formda, personelin yaş, cinsiyet, medeni durum, çocuk sayısı, eğitim durumu, kurumda çalışma süresi, kurumda çalışmaktan memnuniyet duyma durumu, stresle baş etme konusunda eğitim alma durumuna ilişkin sekiz soru yer almaktadır.

Algılanan Stres Ölçeği (ASÖ -14): ASÖ-14, Cohen, Kamarck ve Mermelstein (1983)tarafından geliştirilmiştir. Ölçek Eskin ve ark. (2013) tarafından Türkçeye çevrilerek geçerlilik ve güvenirliği yapılmıştır. 14 maddeden oluşan ASÖ kişinin hayatındaki birtakım durumların ne derece stresli algılandığını ölçmek için tasarlanmıştır. Katılımcılar her maddeyi "Hiçbir zaman (0)" ila "çok sık (4)" arasında değişen 5'li Likert tipi ölçek üzerinde değerlendirmektedir. Maddelerden olumlu ifade içeren 7'si tersten puanlanmaktadır. ASÖ-14'un puanları 0 ile 56 arasında değişmektedir. 4, 5, 6, 7, 9, 10, 13 ters puanlanan maddelerdir. Ölçeğin Cronbach Alpha değeri 0.84 olarak saptanmıştır. (Eskin ve ark., 2013). Bu çalışmada, ölçeğin Cronbach Alpha değeri 0.80 olarak bulunmuştur.

\section{Eğitimin Uygulanması}

Ön Uygulama: Veri toplama araçlarının anlaşılırlığını, eğitimin süresini ve içeriğini belirlemek amacıyla eğitimden bir hafta öncesinde 10 bakım personeline eğitim verilerek ön uygulama yapılmıştır.

Uygulama: Eğitim öncesinde eğitime katılanlara ASÖ14 uygulanmıştır. Daha sonra iki gün süren 45'er dakikalık iki oturumdan oluşan stres yönetimi eğitimi verilmiştir. Eğitim içeriği oluşturulurken Baltaş ve Baltaş (2016)'ın kitabından yararlanılmıştır. Eğitim ruh sağlığı ve hastalıkları hemşireliği anabilim dalında uzman olan araştırmacının kendisi tarafından yapılmıştır. Eğitimin ilk gününde katılımcılara doğa seslerinin dinletildiği müzik eşliğinde gevşeme egzersizi yaptırılmış ve sonrasında eğitimin ilk oturumu gerçekleştirilmiştir. İkinci günkü oturumun başlangıcında tekrar gevşeme egzersizi yaptırılmış ve eğitimin ikinci oturumu gerçekleştirilmiştir. Eğitim sırasında power point sunumu, video gösterimi, demonstrasyon (gevşeme egzersizi uygulamasında), soru cevap, beyin fırtınası gibi çeşitli öğretim yöntem ve teknikleri kullanılmıştır. Eğitim sonrasında veri toplama formları tekrar uygulanmıştır. Uygulanan eğitimin içeriği Tablo 1 de yer almaktadır.

\section{Araştırmanın Değişkenleri}

Personelin yaş, cinsiyet, medeni durum, çocuk sayısı, eğitim durumu, kurumda çalışma süresi, kurumda çalışmaktan memnuniyet duyma düzeyi, stresle baş etme konusunda eğitim alma durumu bağımsız değişkenleri, ASÖ-14 'ten alacağı puan bağımlı değişkeni oluşturmaktadır.

\section{Istatistiksel Analiz}

Verilerin istatistiksel analizi için SPSS 21.0 (The Statistical Package for the Social Sciences-PC Version 21.0) paket programı kullanıldı. Tanımlayıcı istatistiksel yöntemler olarak sayı $(n)$, yüzde $(\%)$, ortalama ve standart sapma (SD) kullanıldı. Verilerin normal dağılım için uyumluluğu Shapiro-Wilk testi ve $Q Q$ grafikleri kullanılarak değerlendirildi. Eğitim öncesi ve eğitim sonrası ASÖ14'ten alınan puan ortalamalarının karşılaştırılmasında da Bağımlı iki örneklem t testi, Bağımsız iki örneklem $t$ testi ve Tek yönlü varyans analizi kullanıldı.

\section{Araştırmanın Etik Boyutu}

Çalışmaya başlamadan önce Aile ve Sosyal Politikalar Yozgat İ Müdürlügü̈nden ve Bozok Üniversitesi Etik Komisyonu'ndan (06.06.2018 tarihli toplantı kararı) izin alınmıştır. Çalışmaya katılmayı kabul eden personelden yazılı ve sözlü onam alınmıştır. ASÖ14'ün Türkçeye geçerlilik ve güvenirlik çalışmasını yapan Sayın Eskin 'den de e-mail yoluyla izin alındı. 
Tablo 1. Stres yönetimi eğitimi içeriği

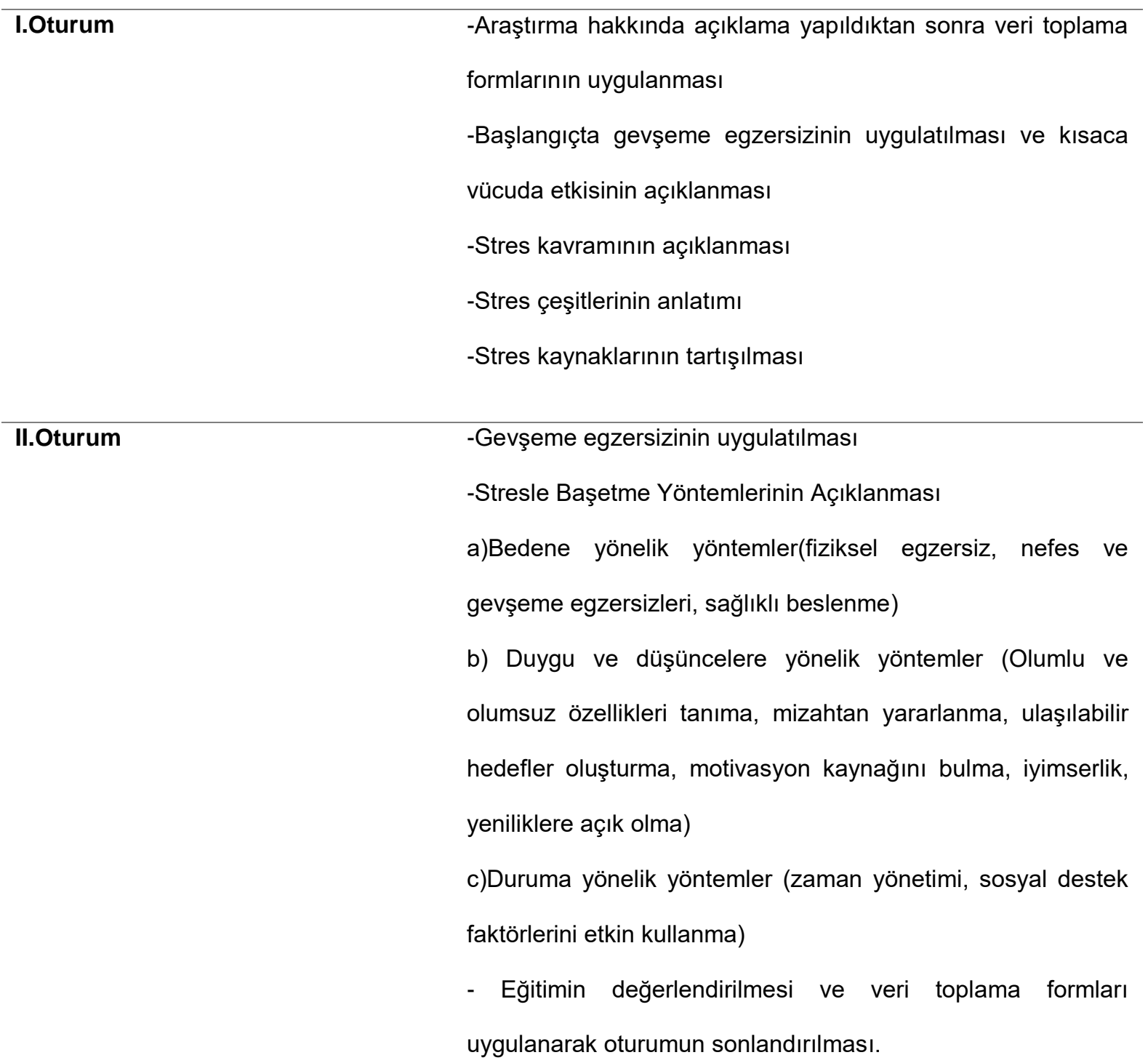

\section{SONUÇLAR}

Tablo 2'de bakım personelinin tanıtıcı özellikleri yer almaktadır. Çalışmaya katılan bakım personelinin yaş ortalaması 41,6 26,5 yıl, \%53,1'i kadın, \%83,7'si evli, \%59,2'si 2 veya daha az sayıda çocuğa sahip, $\% 36,7$ 'si lise mezunu, \%91,6'sı 6 veya daha uzun yıldır kurumda çalışmakta, \%85,7'si kurumda çalışmaktan memnun ve \%81,6'sı stres yönetimi konusunda eğitim almamıştır.

Tablo 3'te bakım personelinin ASÖ14'ten aldığıpuanların ortalamaları yer almaktadır. Personelin puan ortalamalarında ön test ve son test ölçümleri arasında istatistiksel olarak anlamlı bir farklılık saptanmamakla birlikte eğitim sonrasında personelin algıladığı stres düzeyinde bir azalma olduğu saptanmıştır $(p>0,05)$.

Tablo 4'te tanıtıcı özelliklerine göre bakım personelinin eğitim öncesi ve eğitim sonrası ASÖ Puan ortalamaları yer almaktadır. Bakım personelinin tanıtıcı özelliklerine göre eğitim öncesi ve eğitim sonrası ASÖ puan ortalamaları arasında anlamlı bir fark olmamakla birlikte $(p>0,05)$ eğitim sonrası puan ortalamalarında azalma olduğu gözlenmektedir. 
Tablo 2. Bakım personelinin tanıtıcı özellikleri

Tanıtıcı Özellikler

\begin{tabular}{|c|c|c|}
\hline & Sayı & $\%$ \\
\hline \multicolumn{3}{|l|}{ Cinsiyet } \\
\hline Kadın & 26 & 53.1 \\
\hline Erkek & 23 & 46.9 \\
\hline \multicolumn{3}{|c|}{ 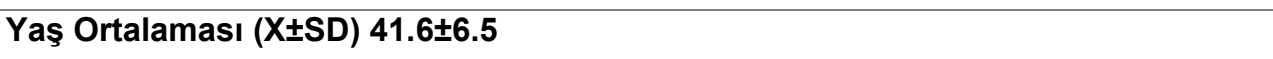 } \\
\hline $29-40$ yaş & 21 & 42.9 \\
\hline $41-52$ yaş & 28 & 57.1 \\
\hline \multicolumn{3}{|l|}{ Medeni Durum } \\
\hline Bekar & 3 & 6.1 \\
\hline Evli & 41 & 83.7 \\
\hline Boşanmış & 5 & 10.2 \\
\hline \multicolumn{3}{|l|}{ Çocuk Sayısı } \\
\hline $0-2$ & 29 & 59.2 \\
\hline 3 ve üzeri & 20 & 40.8 \\
\hline \multicolumn{3}{|l|}{ Eğitim Durumu } \\
\hline İlkokul & 15 & 30.6 \\
\hline Ortaokul & 14 & 28.6 \\
\hline Lise & 18 & 36.7 \\
\hline Yüksekokul ve üzeri & 2 & 4.1 \\
\hline \multicolumn{3}{|c|}{ Kurumda Çalışma Süresi } \\
\hline 5 yıl ve altı & 9 & 18.4 \\
\hline $6-10 \mathrm{yll}$ & 20 & 40.8 \\
\hline 11 yıl ve üzeri & 20 & 40.8 \\
\hline \multicolumn{3}{|c|}{ Kurumda Çalışmaktan Memnun OIma Durumu } \\
\hline Evet & 42 & 85.7 \\
\hline Kısmen & 7 & 14.3 \\
\hline \multicolumn{3}{|c|}{ Stres Eğitimi Alma Durumu } \\
\hline Evet & 9 & 18.4 \\
\hline Hayır & 40 & 81.6 \\
\hline
\end{tabular}

Tablo 3. Bakım personelinin Algılanan Stres Ölçeği 14 puan ortalamaları

\begin{tabular}{ccccc}
\hline ÖLÇEK & Ön Test & Son Test & & Test \\
& $\underline{(\mathbf{X} \pm \mathbf{S S})}$ & $\underline{(\mathbf{X} \pm \mathbf{S S})}$ & $\mathbf{t}$ & $\mathbf{p}$ \\
\hline ASÖ14 & $38,46 \pm 7,89$ & $37,3 \pm 8,10$ & 1.039 &, 304
\end{tabular}

* Bağımlı Gruplarda t testi 
Tablo 4. Bakım personelinin tanımlayıcı özelliklerine göre eğitim öncesi ve sonrası ASÖ puan ortalamaları

\begin{tabular}{|c|c|c|c|}
\hline ÖZELLİKLER & Eğitim Öncesi & Eğitim Sonrası & Test \\
\hline & $\mathrm{X} \pm S S$ & XESS & $\mathbf{p}$ \\
\hline \multicolumn{4}{|l|}{ Cinsiyet } \\
\hline Kadın & $38.61 \pm 8.58$ & $35.65 \pm 10.21$ & 0.117 \\
\hline Erkek & $38.30 \pm 7.22$ & $38.27 \pm 4.20$ & 0.454 \\
\hline$p^{*}$ & 0.892 & 0.131 & \\
\hline \multicolumn{4}{|l|}{ Yaş Ortalaması } \\
\hline $29-40$ yaş & $37.80 \pm 7.06$ & $37.70 \pm 6.61$ & 0.641 \\
\hline $41-52$ yaş & $39.41 \pm 8.41$ & $37.03 \pm 9.09$ & 0.167 \\
\hline$p^{*}$ & 0.419 & 0.929 & \\
\hline \multicolumn{4}{|l|}{ Medeni Durum } \\
\hline Bekar & $35.87 \pm 9.04$ & $36.50 \pm 4.4$ & 0.456 \\
\hline Evli & $39.36 \pm 7.44$ & $37.46 \pm 8.67$ & 0.105 \\
\hline$p^{*}$ & 0.072 & 0.762 & \\
\hline \multicolumn{4}{|l|}{ Çocuk Sayısı } \\
\hline $0-2$ & $38.03 \pm 7.75$ & $38.68 \pm 6.12$ & 0.573 \\
\hline 3 ve üzeri & $39.10 \pm 8.26$ & $35.30 \pm 10.17$ & 0.842 \\
\hline$p^{*}$ & 0.344 & 0.980 & \\
\hline \multicolumn{4}{|l|}{ Eğitim Durumu } \\
\hline İlköğretim & $40.06 \pm 7.41$ & $37.20 \pm 8.70$ & 0.091 \\
\hline Lise ve üzeri & $35.94 \pm 8.17$ & $37.47 \pm 7.27$ & 0.176 \\
\hline$p^{*}$ & 0.344 & 0.980 & \\
\hline \multicolumn{4}{|c|}{ Kurumda Çalışma Süresi } \\
\hline $0-5$ yıl & $38.44 \pm 4.55$ & $40.22 \pm 2.81$ & 0.196 \\
\hline $6-10 \mathrm{yll}$ & $39.95 \pm 7.44$ & $38.20 \pm 7.22$ & 0.432 \\
\hline 11 yıl ve üzeri & $37.00 \pm 9.42$ & $35.10 \pm 10.02$ & 0.231 \\
\hline $\mathrm{p}^{\star \star}$ & 0.075 & 0.910 & \\
\hline \multicolumn{4}{|c|}{ Kurumda Çalışmaktan Memnun Olma Durumu } \\
\hline Evet & $38.26 \pm 8.43$ & $36.88 \pm 8.53$ & 0.291 \\
\hline Kısmen & $39.71 \pm 3.35$ & $39.85 \pm 4.29$ & 0.916 \\
\hline$p^{*}$ & 0.657 & 0.374 & \\
\hline \multicolumn{4}{|c|}{ Stres Eğitimi Alma Durumu } \\
\hline Alanlar & $37.55 \pm 11.51$ & $36.77 \pm 13.72$ & 0.623 \\
\hline Almayanlar & $37.57 \pm 6.53$ & $38.55 \pm 5.73$ & 0.384 \\
\hline$p^{*}$ & 0.863 & 0.720 & \\
\hline
\end{tabular}

\section{TARTIŞMA}

Bakım ve rehabilitasyon merkezlerinde görev yapmakta olan bakım personeli kurumlarda verilen bakım hizmetini sağlamada önemli rol ve sorumluluklar üstlenmişlerdir ve kurumda bakım alan bireylerle en çok etkileşimde olan meslek grubunu oluşturmaktadır. Yapılan çalışmalarda (Hendekçi ve Uğur, 2020; Başol, Sağlam ve Çakır, 2018; Işıkhan, 2018; Islam et al., 2017; Danış ve ark., 2011; Brigstocke, Donaldson ve Lalit, 2005) bakım personelinin yaşadığı sorunların başında stresin yer aldığı belirtilmektedir. $\mathrm{Bu}$ çalışmada bakım personeline uygulanan stres yönetimi eğitiminin bakım personelinin algıladıkları stres düzeyine etkisinin değerlendirilmesi amaçlanmıştır.

Çalışmamızda, bakım personelinin eğitim öncesi ve eğitim sonrası ASÖ-14'ten aldığı puan ortalamaları arasında azalma olmakla birlikte istatistiksel olarak anlamlı bir farklılık saptanmamıştır. $\mathrm{Bu}$ nedenle $\mathrm{HO}$ hipotezi kabul edilmiştir. Bu sonuç doğrultusunda verilen eğitimin stresi azaltmada olumlu bir etkisinin olduğunu fakat yeterli olmadığını söyleyebiliriz. Literatür incelendiğinde Türkiye'de bakım personelinin stresini azaltmaya yönelik yapılmış bir çalışmayla karşılaşılmamıştır. Yurt dışında ise yapılan çok az sayıda çalışmada bakım personelinin stresini azaltmaya yönelik uygulanan programların bakım 
personellerinin stres düzeyini azalttığını gösteren sonuçlar yer almaktadır. Baker, Huxley, Dennis ve ark. (2015) demanslı bireylere bakım veren personele yönelik uyguladıkları 20 hafta süren web tabanlı stresle başetme eğitim programının bireylerin stresini azalttığını saptamışlardır. McConachie et al. (2014), zihinsel engeli olan bireylere bakım veren bakım personeline yönelik uyguladıkları kabul ve bilinçli farkındalık temelli stres yönetimi eğitiminin bakım personelinin stres düzeyini azalttığını ve öznel iyi oluş düzeylerini artırdığını belirtmişlerdir. Çalışmamızda uygulanan eğitimle bireylerin algıladığı stres düzeyinde anlamlı bir azalma olmaması, uygulanan eğitim programının özelliklerinden (eğitimin süresi, uygulandığı ortam vb.) ayrıca eğitimin hemen sonrasında yapılan anlık bir ölçüm yapılması sonucun bu şekilde olmasında etkili olabileceğini düşündürmektedir.

Çalışmamızda, eğitime katılan bakım personelinin cinsiyet değişkenine göre eğitim öncesinde ve sonrasında yapılan ölçümlerde ASÖ14 puan ortalamaları arasında istatistiksel olarak anlamlı bir farklılık saptanmamıştır. Ancak literatürde, cinsiyet değişkeninin, algılanan stres düzeyi üzerinde etkisi olduğunu gösteren çalışma (Kakemam et al., 2019; Parmar et al, 2015; Savcı ve Aysan, 2014; Mısra et al., 2000) sayısı oldukça fazladır. Kadınların üstlendiği çoklu rollerin ve toplumun çalışan kadın üzerindeki oluşturduğu baskının kadınların erkeklere göre algıladıkları stres düzeyinin daha fazla olmasına neden olduğu belirtilmektedir (Özçelik, 2017). Çalışmamızın sonuçlarının literatürle uyumlu olmamasında eğitim programının etkisinin kaynaklanmış olabileceğini söyleyebiliriz.

$\mathrm{Bu}$ çalışmada bazı sınırlılıklar bulunmaktadır. Araştırmanın yalnızca bir ildeki bakım ve rehabilitasyon merkezinde yapılmış olması, sonuçların genellenebilirliği açısından bir sınırlılıktır. $\mathrm{Bu}$ nedenle benzer çalışmaların daha büyük örneklemli gruplar üzerinde ve farklı illerde yapılması önerilmektedir. Ayrıca çalışmanın bir diğer sınırılığı da izleme ölçümü yapılmamış olmasıdır. Bu durum çalışmanın sonuçlarının uzun süreli etkisini değerlendirmeyi engellemektedir.Bundan sonra yapılacak çalışmalarda bu sınırlılıkların dikkate alınmasının uygun olacağı düşünülmektedir.

\section{Sonuç}

Araştırmanın sonucunda uygulanan stres yönetimi eğitiminin bakım personelinin stresini azaltmada anlamlı etkisi olmadığı saptanmıştır fakat eğitim sonrası algıladıkları stres düzeyinde azalma olması olumlu bir gelişmedir. Araştırmadan elde edilen sonuçlara göre yeni yapılacak çalışmalarda, pekiştirici nitelikte daha fazla oturumdan oluşan eğitimler uygulanıp uygulanan eğitimin uzun dönemdeki etkisinin araştırılması önerilebilir. Bu programların oluşturup geliştirilmesinde sağlık çalışanlarına önemli rol ve sorumluklar düşmektedir.

\section{Araştırmacıların Katkı Oranı}

Çalışmanın bütün aşamaları araştırmacı tarafından gerçekleştirilmiştir bu nedenle çıkar çatışması bulunmamaktadır.

\section{Destek/Teşekkür}

Eğitim programının düzenlenmesinde destek olan kurum yöneticilerine ve araştırmaya katılan bakım personeline değerli katkılarından dolayı teşekkür ederim.

\section{Kaynaklar}

Asıcı, E., \& Uygur, S. S. (2017). Duygusal öz-yeterlik ve affetmenin algılanan stres düzeyini yordayıcı rolü. Insan ve Toplum Bilimleri Araştırmaları Dergisi, 6(3), 13531375

Atagün, M. İ., Balaban, Ö. D., Atagün, Z., Elagöz, M., \& Özpolat Y. A. (2011). Psikiyatride Güncel Yaklaşımlar, 3(3), 513552

Baltaş, A., \& Baltaş, Z. (2016). Stres ve başa çıkma yolları, (19.Baskı, ss.1-326). İstanbul:.Remzi Kitabevi.

Baker, C., Huxley, P., Dennis, M., Islam, S., \& Russell, I. (2015). Alleviating staff stress in care homes for people with dementia: protocol for stepped-wedge cluster randomised trial to evaluate a web-based MindfulnessStress Reduction course. BMC Psychiatry, 15, 317-325.

Bakım Kavramının Tanımı. (11.02.2019). Erişim adresi: http://www.tdk.gov.tr/index.php?option=com gts\&kelime $=\mathrm{BAKIM}$.

Bakım Merkezi. (11.02.2019). Erişim adresi: https://alo183.aile.gov.tr/mevzuatbilgiportali/rehabilitasyon-merkezi.

Bayrak, B., Oğuz, S., Arslan S., Candar, B., Keleş, S., \& Karagöz, B., et al. (2019). Miyokard infarktüsü geçirmiş hastalarda algılanan stresin belirlenmesi. Kardiyovasküler Hemşirelik Dergisi, 10(23), 129-137. https://doi.org/10.5543/khd.2019.09719

Başol, O., Sağlam, Y., \& Çakır N. N. (2018). Engelli ve yaşlı bakım personelinin tükenmişlik seviyeleri ile çalışma yaşamı kalitesi algısı ilişkisi. Toplum ve Sosyal Hizmet, 29, 2, 71-97.

Yaşlanan Toplum. Bilir, N. (2004). (23.01.2019). Erişim adresi: http://www.geriatri.org.tr/pdfler/YaslananToplum.pdf.

Brigstocke, G., Donaldson, N., \& Lalit, K. (2005). Determinants of caregiving burden and quality of life in caregivers of stroke patients. Stroke, 36, 2181-2186. https://doi.org/10.1161/01.STR.0000181755.23914.53

Cohen, S., Kamarck, T., \& Mermelstein, S. (1983). A global measure of perceived stress. J Health Soc Behav, 24, 385-396.

Danış, M. Z., \& Genç, Y. (2011). Kurumsal bakım elemanlarının genel özellikleri ve yaşadıkları sorunlar. Yalova Sosyal Bilimler Dergisi, 1(2), 170-183.

Dölek, B. Ö. (2012). Evde ve kurumda uzun dönemli bakım. Klinik Gelişim, 25, 95-99.

Dönmez, K. H., Kolukısa, S., \& Altundaş D. N. (2020)Comprasion of folk dancers' perceived stress levels 
and problem solving skills. Journal of Current Researches on Social Sciences, 10(4), 821-834.

Engelli Bireylere Yönelik Özel Bakım Merkezleri Yönetmeliği. (09.05.2021). Engelli Bireylere Yönelik Özel Bakım Merkezleri Yönetmeliği (04.11.2016). Erişim adresi: https://www.resmigazete.gov.tr/eskiler/2016/11/2016110 4-2.htm.

Eskin, M., Harlak, H., Demirkıran, F., \& Dereboy, Ç. (2013). Algılanan stres ölçeğinin türkçeye uyarlanması: Güvenirlik ve geçerlik analizi. Yeni Symposium, 51(3), 132-140. https://doi.org/10.1186/s12888-015-0703-7

Folkman, S., Lazarus, R. S., Pimpley, S. \& Novacek, J. (1987). Age differences in stress and coping processes. Psychology and Aging, 2 (2), 171-184.

Gel, T.K., \& Keskin, M. (2017). Informal bakım verenlerin bakım yüküne ilişkin hemşirelerin görüşleri. Anadolu Hem Sağ Bil Derg, 20(4), 267-78.

Hendekçi, A., \& Uğur, G. H. (2020). Bakım personellerinin yaşadığı sorunlar ve bakımdan etkilenme durumları. JAREN, 6(3),

$538-44$. https://doi.org/10.5222/jaren.2019.66588

Islam, M. S., Baker, C., Huxley, P., Russell, I. T., \& Dennis, M. S. The nature, characteristics and associations of care home staff stress and wellbeing: a national survey. BMC Nursing, 16 (22), 1-10.

Işıkhan, V. (2018). Kurumda çalışan yaşlı bakım elemanlarının bakım yükünü etkileyen faktörlerin incelenmesi. Toplum ve Sosyal Hizmet, 29(1), 1-26.

Kakemam, E., Raeissi, P., Raoofi, S., Soltani, A., Sokhanvar, M., Visentin, D. C., \& Cleary, M. Occupational stress and associated risk factors among nurses: a cross-sectional study. Contemporary Nurse, 55(2-3), 237-249.

Koç, S., Özkul, A. S., Ürkmez D. Ö., Özel H. Ö., \& Çevik L. Ç. (2017). Bir sağlık kuruluşunda görev yapmakta olan hemşirelerin stres kaynaklarının ve düzeylerinin analizi. Okmeydanı Tıp Dergisi, 33(2), 68-75.

Kusmaul, N., Bern-Klug, M. \& Bonifas, R. (2017). Ethical issues in long term care: a human rights perspective. Journal of Human Rights and Social Work, 2, 86-97. https://doi.org/10.1007/s41134-017-0035-2

Long-Term Care and Social Justice. (11.02.2019). Erişim adresi:

https://www.who.int/mediacentre/news/notes/ethical_choi ces.pdf/

Misra, R., Mckean, M., West, S., \& Russo, T. (2000). Academic stress of college students: comparison of student and faculty perceptions. College Student Journal, 8(30), 2741.

McCarthy, V. J. C., Power, S. \& Greiner, B. A. (2010). Perceived occupational stress in nurses working in Ireland. Occupl Med.(Lond), 60, 604-610.

McConachie, D. A. J., McKenzie, K., Morris P. G., \& Walley R. M. (2014). Acceptance and mindfulness-based stress management for support staff caring for individuals with intellectual disabilities. Res Dev Disabil, 35(6), 1216-27. https://doi.org/10.1016/j.ridd.2014.03.005.

Nüfus İstatistikleri. (11.02.2019). Türkiye Nüfus İstatistikleri (2015). Erişim adresi: http://www.tuik.gov.tr/UstMenu.do?metod=temelist.

Özçelik, K. M. (2017). Çalışma hayatında kadının yeri ve kariyer gelişim engelleri. Akademik Sosyal Araştırmalar Dergisi, 5 (52), 49-70.

Parmar, K., Solanki, C., Parikh, M., \& Vankar, G. K. (2015). Gender differences in stress at work place among doctors and nurses. GCSMC J Med Sci., 4,2, 108-113.

Savcı, M., \& Aysan, F. (2014). Üniversite öğrencilerinde algılanan stres düzeyi ile stresle ile başaçıkma stratejileri arasındaki ilişki. Uluslararası Türk Eğitim Bilimleri Dergisi, Ekim, 44-56.

Turan, N., Durgun, H., Kaya, H., Ertaş, G., \& Kuvan, D. (2019). Hemşirelik öğrencilerinin stres durumları ile bilişsel esneklik düzeyleri arasındaki ilişki. JAREN, 5(1), 59-66. https://doi.org/10.5222/jaren.2019.43265

Yağmur, T., \& Türkmen, S. N. (2017). Ruhsal hastalığı olan hastalara bakım veren aile üyelerinde algılanan stres ve psikolojik dayanıkılık, MCBU-SBED, 4(1), 542-548.

Zarit, S. H. (2004). Family care and burden at the end of life. Commentary, 8, 170 (12), 1811-1812. 